\title{
PEMANFAATAN TEKNOLOGI DALAM PEMBELAJARAN MATEMATIKA
}

\section{Oleh}

\section{Jeriadi}

\section{Jeriadi1997@gmail.com}

\begin{abstract}
Abstrak
Mata pelajaran matematika merupakan mata pelajaran wajib di seluruh jenjang pendidikan. Tujuan utama dari mata pelajaran ini adalah untuk membekali siswa dengan kemampuan berpikir logis, analitis, sistematis, kritis, dan kreatif, serta mampu bekerjasama. Namun pada kenyataannya dilapangan, banyak yang berasumsi bahwa 'Matematika itu sulit' sehingga menyebabkan kurangnya minat dan motivasi siswa dalam belajar matematika. Dengan semakin pesatnya perkembangan teknologi dalam kehidupan kita, kita harus bisa memanfaatkannya dalam bidang pendidikan matematika untuk mempermudah guru maupun siswa dalam proses belajar mengajar. Salah satunya adalah pemanfaatan aplikasi Edmodo, geogebra, Whatsapp, dan Microsoft teams. Dengan menggunakan media tersebut, banyak memberi dampak positif terhadap proses belajar mengajar. Salah satunya adalah mempermudah guru dalam menjelaskan materi kepada siswa, sehingga siswa juga lebih cepat memahami materi.

Kata kunci: Matematika, Teknologi, Guru, Siswa
\end{abstract}

\section{A. Latar Belakang}

Mata pelajaran matematika merupakan mata pelajaran wajib di seluruh jenjang pendidikan. Tujuan utama dari mata pelajaran ini adalah untuk membekali siswa dengan kemampuan berpikir logis, analitis, sistematis, kritis, dan kreatif, serta mampu bekerjasama. Namun, Ironisnya adalah pelajaran matematika oleh sebagian besar siswa 
dianggap ‘sangat menakutkan', sehingga siswa kurang motivasi dalam mengikuti proses pembelajaran. ${ }^{1}$

Di era globalisasi saat ini, teknologi memiliki peran yang sangat penting dalam hampir setiap aspek kehidupan, baik dalam keseharian maupun dalam dunia pendidikan, termasuk dalam bidang pendidikan matematika. ${ }^{2}$ Dalam dunia pendidikan teknologi sangat banyak dampak positifnya, salah satu manfaatnyanya adalah dengan adanya Kalkulator, aplikasi Edmodo, Geogebra, dll.

Tulisan ini mengkaji bagaimana teknologi dapat dimanfaatkan untuk mempermudah penyampaian mata pelajaran matematika. Teknologi dapat digunakan sebagai media di setiap tahap dalam proses pembelajaran, mulai dari tahap persiapan sampai tahap evaluasi bahkan dapat digunakan juga dalam menjaring umpan balik.

\section{B. Rumusan Masalah}

1. Bagaimana pembelajaran berbasis aplikasi Edmodo?

2. Bagaimana pembelajaran berbasis aplikasi Whatsapp?

3. Bagaimana pembelajaran berbasis aplikasi Geogebra?

4. Bagaimana pembelajaran berbasis aplikasi Microsoft Teams?

\section{Tujuan Penulisan Makalah}

Tujuan penulisan makalah ini adalah untuk lebih memahami tentang pemanfaatan teknologi dalam pembelajaran matematika, salah satunya adalah Edmodo, whatsapp, geogebra dan ms. Teams. Tujuan lain dari penulisan makalah ini adalah untuk memenuhi tugas UTS mata kuliah Metodologi Penelitian Pendidikan Matematika.

\footnotetext{
${ }^{1}$ Rosalina, "Pemanfaatan TIK Sebagai Media Pembelajaran Di Masa Depan”, Jurnal Teknik Informatika, 2009, 12-34.

2 Al Jupri, "Peran Teknologi Dalam Pembelajaran Matematika Dengan Pendekatan Matematika Realistik," Seminar Nasional Matematika Dan Pendidikan Matematika, 2018, 303-14.
} 


\section{A. Pembelajaran Berbasis Aplikasi Edmodo}

Matematika merupakan salah satu mata pelajaran wajib pada jenjang sekolah dasar, sekolah menengah pertama dan sekolah menengah atas. Pembelajaran matematika membutuhkan interaksi antara guru dan siswa serta antarsiswa untuk menyelesaikan sebuah masalah matematika. Suatu proses belajar mengajar akan menjadi efektif jika para pembelajar saling mengkomunikasikan ide melalui interaksi sosial. ${ }^{3}$

Perkembangan teknologi sudah banyak memberikan pengaruh terhadap cara hidup kita, salah satunya adalah dalam bidang pendidikan dengan penggunaan $e$-learning dalam kegiatan pembelajaran di sekolah maupun perguruan tinggi. E-learning dapat digunakan sebagai alternatif atas permasalahan dalam bidang pendidikan, baik sebagai tambahan, pelengkap maupun pengganti atas kegiatan pembelajaran yang sudah ada. E-learning adalah Pembelajaran yang disusun dengan tujuan menggunakan sistem elektronik atau komputer sehingga mampu mendukung proses pembelajaran.

Salah satu aplikasi pada internet yang bisa digunakan untuk e-learning adalah Edmodo. Edmodo adalah sebuah platform pembelajaran sosial untuk guru/dosen, siswa/mahasiswa maupun untuk orang tua/wali yang dikembangkan pada akhir 2008 oleh Nic Borg dan Jeff O'Hara. ${ }^{4}$ Dengan aplikasi edmodo siswa atau mahasiswa dapat dikontrol secara berkelanjutan oleh orang tua dengan adanya akun kontrol yang terhubung kepada orang tua siswa atau mahasiswa.

Belajar menggunakan media edmodo membuat pembelajaan menjadi lebih praktis dan meningkatkan minat belajar siswa. Dengan aplikasi ini, pendidik atau dosen dapa lebih mudah memantau peserta didik atau siswanya dari jarak jauh.

Pembelajaran berbasis aplikasi Edmodo cukup memberi dampak yang besar terhadap pembelajaran, apalagi untuk situasi pandemi seperti saat ini. Dimana pemerintah melarang pembelajaran tatap muka demi menghindari penyebaran virus COVID-19.

\footnotetext{
${ }^{3}$ Irmayanti, Nurul Islamiah, and Syarifuddin, “Analisis Sosiomatematika Berbasis Kearifan Lokal Dalam Pembelajaran Pada Siswa Sdn 224 Palae", JTMT: Jurnal Tadris Matematika 1, no. 2 (2020): 27-34. ${ }^{4}$ Anggi Heriyanti, Prima Mytra, Meisaraswaty A, "Kepraktisan Pembelajaran Menggunaknan Aplikasi Edmodo", JTMT: Jurnal Tadris Matematika 1, no. 2 (2020): 9-11.
} 
Edmodo sendiri memiliki berbagai macam fitur unik, diantaranya:

1. Polling

Fitur ini hanya dapat diakses oleh guru atau pendidik yang biasanya difungsikan untuk mengetahui bagaimana tanggapan siswa atau peserta didiknya mengenai halhal tertentu. Dengan fitur ini, seorang guru mampu mendapatkan feedback dengan cepat dari siswanya.

2. Gradebook

Fitur ini mirip dengan catatan nilai peserta didik. Dengan fitur ini, seorang guru mampu megelola dan menginput nilai siswanya dengan mudah. Karena sistemnya bisa otomatis maupun input manual.

3. File dan links

Fitur ini adalah tempat dimana seseorang, baik guru maupun siswa dapat mengirimkan sebuah lampiran file atau link. Biasanya guru ketika menjelaskan materi membutuhkan sebuah gambar atau dokumen lainnya yang biasanya memiliki eksistensi .doc, .ppt, .docx, dll. Dalam fitur ini guru bisa mengupload doumen yang diinginkannya, sehingga memudahkannya dalam menyampaikan materi pembelajaran kepada siswa.

4. Quiz

Fitur ini hanya dapat dibuat oleh guru, sedangkan siswa tidak memiliki akses untuk membuat kuisnya. Siswa hanya dapat mengaksesnya dalam tujuan untuk menjawab quiz yang diberikan oleh gurunya. fitur ini sangat efektif karena guru dapat melakukan evaluasi hasil belajar siswanya dengan fitur ini, baik berupa pilihan ganda, uraian maupun isian singkat.

Dengan fitur ini, quiz pun terasa lebih modern dan mengikuti pergembangan zaman, karena guru dapat menambahkan sebuah gambar ataupun video dalam soal quiznya, sehingga visualisasinya lebih nyata.

5. Library

Fitur ini merupakan salah satu fitur yang sangat penting bagi guru, karena dengan fitur ini guru dapat menampung semua filenya disini, meski sampai ribuan file. Seperti gambar, video, dokumen, dll. 
6. Assignment

Fitur ini adalah fitur yang bisa digunakan oleh guru untuk memberikan penugasan kepada siswanya secara online. Fitur ini mirip dengan fitur yang ada pada ms. Teams, dimana dalam fitur ini juga terdapat tenggat waktu untuk pengumpulan tugasnya.

7. Award Badge

Fitur ini adalah salah satu fitur yang unik pada Edmodo, disbanding dengan aplikasi lainnya. Dalam fitur ini, guru dapat memberikan predikat atau penghargaan kepada siswanya yang memiliki trsck record terbaik dalam mengerjakan tugas dan quiz.

8. Prent Code

Fitur ini sangat mebantu juga, karena setiap kali siswa membuat akun, maka otomatis Ia juga mendapatkan sebuah parent code yang dapat digunakan oleh orang tua atau walinya untuk membuat akun khusus orang tau atau wali.

Dengan fitur ini, orang tua dapat memantau semua aktivitas belajar anakanaknya.

\section{B. Pembelajaran Berbasis Aplikasi Whatsapp}

Hal yang paling penting dalam pembelajaran yang harus diperhatikan adalah proses, bukan semata-mata hasil akhir. Olehnya itu, proses pembelajaran tidak dapat dianggap enteng karena didalamnya terdapat nilai yang sangat penting yang akan mencerminkan kemampuan siswa. ${ }^{5}$

Ditengah situasi pandemi seperti sekarang ini, pembelajaran terpaksa dilakukan di rumah yang membuat para guru maupun siswa harus memanfaatkan berbagai teknologi yang ada saat ini demi menunjang keberlangsungan proses pembelajaran. Salah satu teknologi yang bisa digunakan dalam proses pembelajaran secara daring adalah dengan menggunakan media whatsapp.

\footnotetext{
${ }^{5}$ Nurjannah et al., “Analisis Kesalahan Siswa Dalam Memecahkan Masalah Pisa Ditinjau Dari Gender," JTMT : Jurnal Tadris Matematika 1, no. 2 (2020): 1-8.
} 
Media whatsapp menjadi salah satu pilihan yang dapat digunakan dalam proses pembelajaran secara daring karena whatsapp memiliki beberapa kelebihan secara umum dibanding dengan media-media online lainnya. Diantaranya, karena whatsapp merupakan media yang terbilang lebih mudah dijangkau oleh semua kalangan termasuk siswa yang tinggal di daerah pedalaman yang koneksi jaringan internetnya kurang memadai. Selain itu, whatsapp juga merupakan media yang lebih hemat dipakai sebab tidak memerlukan kuota internet yang mahal dibanding dengan media-media lain. ${ }^{6}$

Whatsapp bisa menjadi alternative lain ketika aplikasi yang lainnya mengalami masalah jaringan, karena whatsapp tidak memerlukan koneksi jaringan yang tinggi untuk bisa terhubung. Pengguna dapat mengaksesnya dengan mudah karena memiliki fitur yang simple. Mayoritas siswa pun lebih menyukai pembelajaran menggunakan media whatsapp.

Media Whatsapp adalah salah satu media atau alat yang digunakan untuk memudahkan seseorang dalam berkomunikasi satu sama lain. Whatsapp memiliki dampak besar dalam menunjang pembelajaran, apalagi di masa sekarang ini. ${ }^{7}$

Media Whatsapp sangat berguna dalam situasi pandemi seperti saat ini. Bukan hanya dalam dunia pendidikan, tetapi dalam dunia bisnis, dll juga sangat terbantu dengan adanya WhatsApp. Dalam dunia pendidikan sendiri, guru sangat terbantu dengan adanya whatsapp. Guru lebih mudah berkomunika, baik komunikasi dengan siswa ataupun dengan sesama guru dan orang tua siswa.

Dalam aplikasi Whatsapp, guru dapat memantau siswanya dengan menggunakan salah satu fitur yang ada dalam aplikasi tersebut, yaitu fitur Video Call atau biasa disingkat dengan VC.

Selain itu, Whatsapp juga terdapat fitur lainnya, seperti Voice note, Chat, Chat Grup, dll.

\footnotetext{
${ }^{6}$ Nurhikmah and Ernawati, "Pengaruh Model Team Assisted Individualization (Tai) Terhadap Kemampuan Berpikir Kritis Matematis Siswa Berbasis Media Whatsapp", JTMT: Jurnal Tadris Matematika 1, no. 2 (2020): 19-26.

${ }^{7}$ Annisa Rahayu, Ernawati, and Rizki Ashari Rahim, “Perbandingan Hasil Belajar Matematika Dengan Menggunakan Model Number Head Together (Nht) Dan Think Pair Share (Tps) Berbasis Media Whatsapp", JTMT: Jurnal Tadris Matematika 1, no. 2 (2020): 12-18.
} 


\section{Pembelajaran berbasis aplikasi Geogebra}

Dalam upaya peningkatan kualitas pendidikan dewasa ini telah dikembangkan penggunaan teknologi informasi di kelas. Metode pembelajaran yang dulunya bersifat tradisional perlahan-lahan mulai ditinggalkan digantikan dengan metode pembelajaran yang lebih modern. ${ }^{8}$ salah satu pemanfaatan teknologi sekarang ini dengan menggunakan adalah aplikasi geogebra.

GeoGebra adalah (software) matematika dinamis yang dapat digunakan sebagai alat bantu dalam proses belajar mengajar matematika. Software ini dikembangkan untuk proses belajar mengajar matematika di sekolah yang diamati paling tidak ada tiga kegunaan yakni; media pembelajaran matematika, alat bantu membuat bahan ajar matematika, menyelesaikan soal matematika. Program ini dapat dimanfaatkan untuk meningkatkan pemahaman siswa terhadap konsep yang telah dipelajari maupun sebagai sarana untuk mengenalkan konsep baru.

GeoGebra merupakan kependekan dari geometry (geometri) dan algebra (aljabar), tetapi program ini tidak hanya mendukung untuk kedua topik tersebut, tapi juga mendukung banyak topik matematika di luar keduanya. ${ }^{9}$

Menurut Hohenwarter dan Fuchs ${ }^{10}$, GeoGebra adalah software serbaguna untuk pembelajaran matematika di sekolah dan perguruan tinggi. Dalam pembelajaran matematika GeoGebra dapat dimanfaatkan sebagai berikut;

1. GeoGebra untuk media demontrasi dan visualisasi.

2. GeoGebra sebagai alat bantu kontruksi.

3. GeoGebra sebagai alat bantu penemuan konsep matematika.

4. GeoGebra untuk menyiapkan bahan-bahan pengajaran. Materi-materi

\footnotetext{
${ }^{8}$ Tatiek Irawati, "Pengelolaan Pembelajaran Matematika Berbasis Teknologi Informasi Untuk Meningkatkan Pemahaman Konsep Dimensi Tiga Di SMK Negeri 1 Sawit Boyolali”, Tesis Magister Pendidikan, 2010, 24-34. ${ }^{9}$ Isman M.Nur, "Pemanfaatan Program Geogebra Dalam Pembelajaran Matematika," Jurnal Matematika Dan Pendidikan Matematika 5, no. 1 (2016): 10-19.

${ }^{10}$ M.Nur.
} 
GeoGebra sangat praktis untuk digunakan dalam pembelajaran, karena fitur-fitur dan tampilan yang dimilikinya sangat sederhana dan mudah untuk di pahami dan dipelajari. Dengan menggunakan aplikasi ini, guru tidak lagi kesusahan dalam menjelaskan materi-materi plajaran matematika. Terutama dalam materi bangundatar, bangun ruang, trigonometri dll. Karena dalam geogebra semuanya mudah untuk dibuat dan dijelaskan.

Menu utama GeoGebra adalah: File, Edit, View, Option, Tools, Windows, dan Help untuk menggambar objek-objek geometri. Menu File digunakan untuk membuat, membuka, menyimpan, dan mengekspor file, serta keluar program. Menu Edit digunakan untuk mengedit lukisan. Menu View digunakan untuk mengatur tampilan. Menu Option untuk mengatur berbagai fitur tampilan, seperti pengaturan ukuran huruf, pengaturan jenis (style) objek-objek geometri, dan sebagainya. Sedangkan menun Help menyediakan petunjuk teknis penggunaan program GeoGebra. Berbagai menu tampilan lainnya akan ditampilkan sebagai berikut 


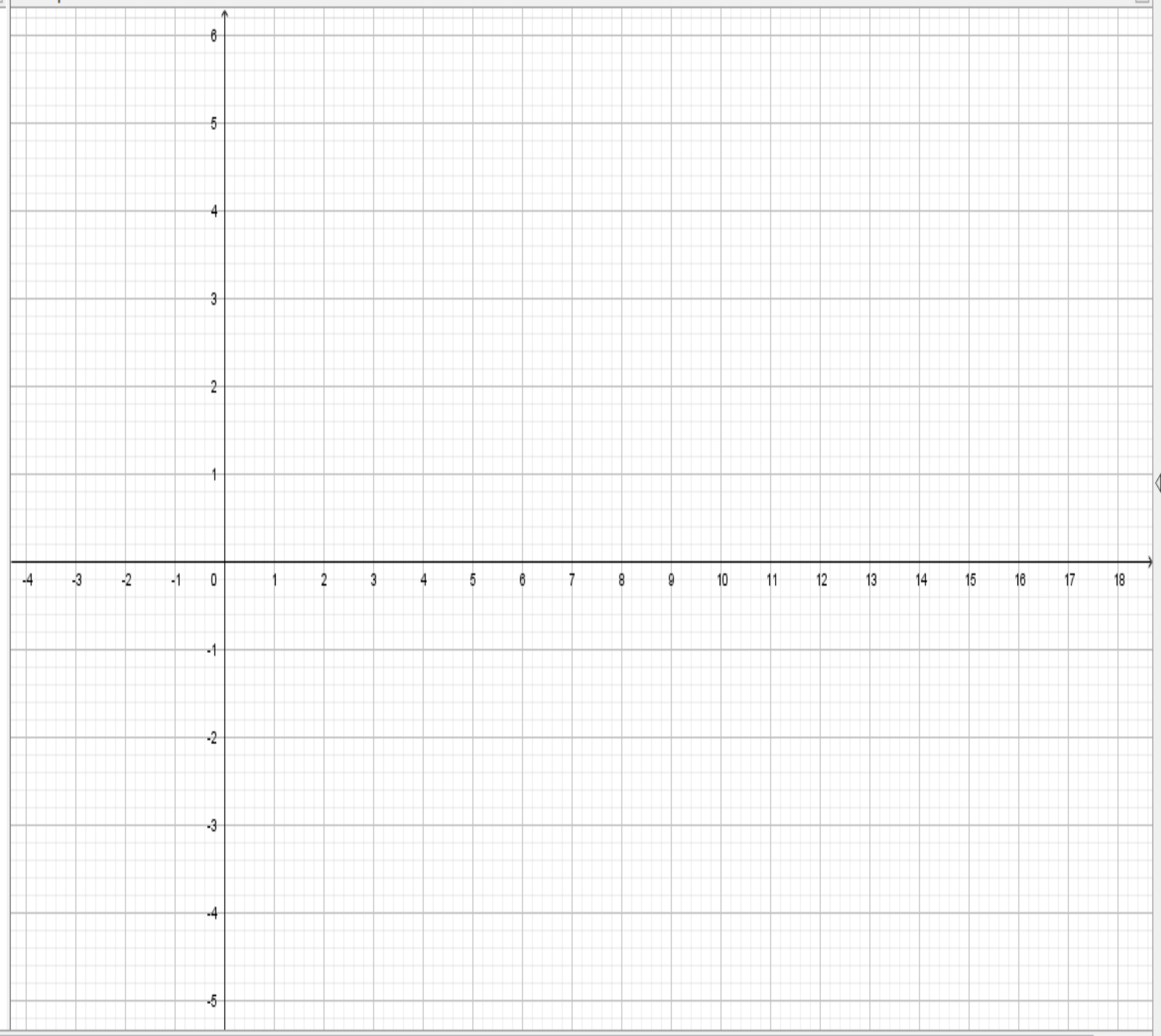

Gambar 1.1Layout Geogebra

\section{Contoh Aplikasi Program Geogebra}

Beberapa contoh penggunaan aplikasi geogebra dalam pembelajaran matematika adalah sebagai berikut: 


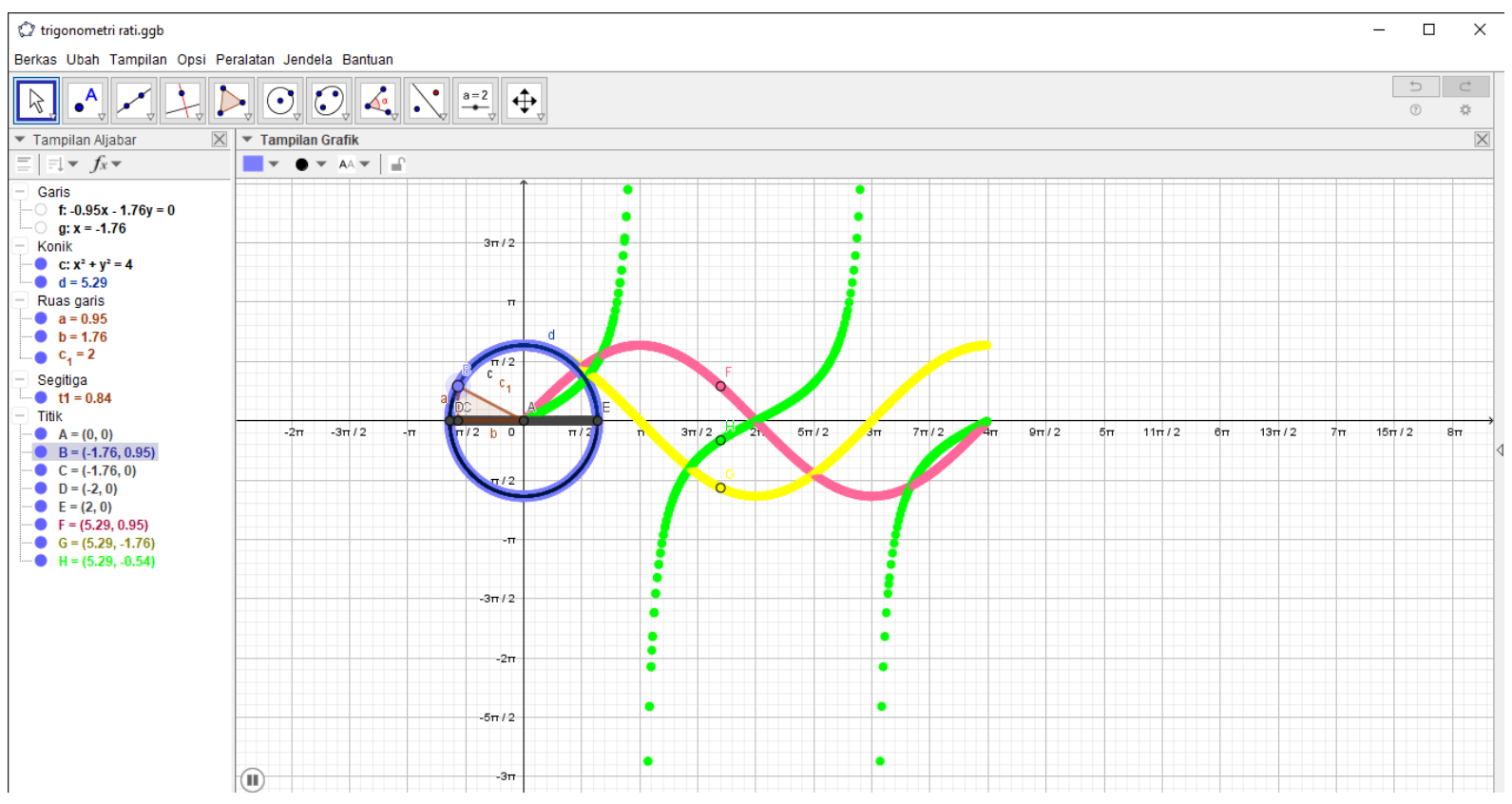

Contoh 1.2 Trigonometri

Pembuatan animasi Trigonometri dengan menggunakan aplikasi Geogebra sangat membantu guru dalam menjelaskan aturan sinus, cosinus dan tangen. Dengan menggunakan metode ini, siswa juga menjadi lebih aktif dan semangat dalam mengikuti proses pembelajaran matematika.

Dengan menggunakan aplikasi Geogebra, guru dapat menjelaskan animasi trigonometri dengan mengaktifkan animasi hidupnya di dalam aplikasi. 


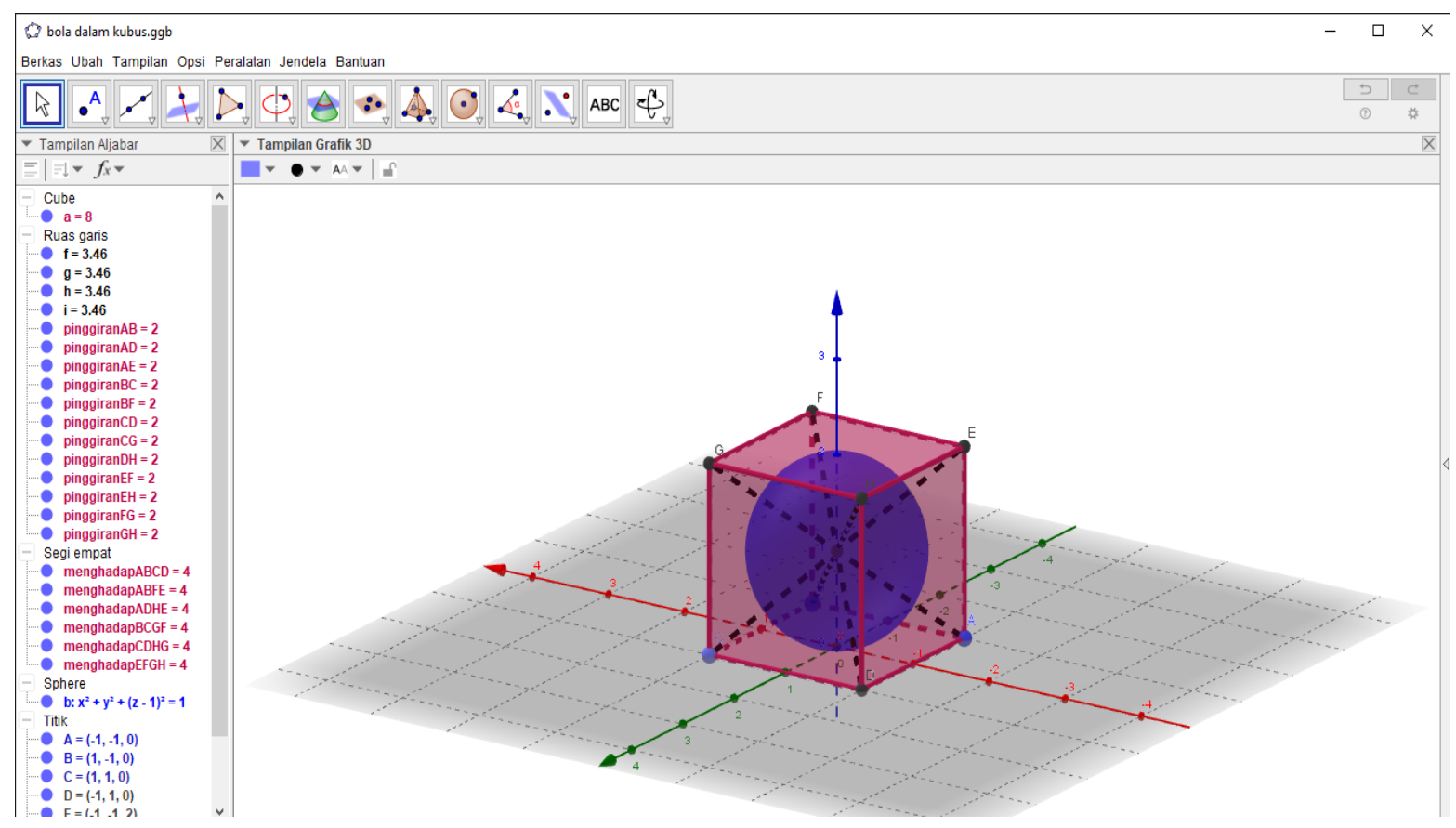

Gambar 1.3 Bola dalam kubus

Pembuatan Bola dalam kubus dengan menggunakan aplikasi Geogebra sangat membantu guru dalam menjelaskan volume bangun ruang yaitu bola dan kubus. Guru lebih mudah dalam menjelaskan cara mencari volume bola dan kubus walaupun hanya panjang rusuk kubusnya yang diketahui.

Dengan menggunakan geogebra siswa juga dapat mengamati langsung gambarnya dalam bentuk tiga dimensi, sehingga lebih memudahkan siswa dalam mempelajarinya dan menghitung volume, luas, keliling dll tanpa harus menggunakan alat bantu lagi yang secara nyata (Bendanya langsung).

Dengan geogebra guru juga lebih efektif dalam penyampaian dan penyajian materi. Karena tidak lagi repot membuatkan gambarnya di papan tulis. 


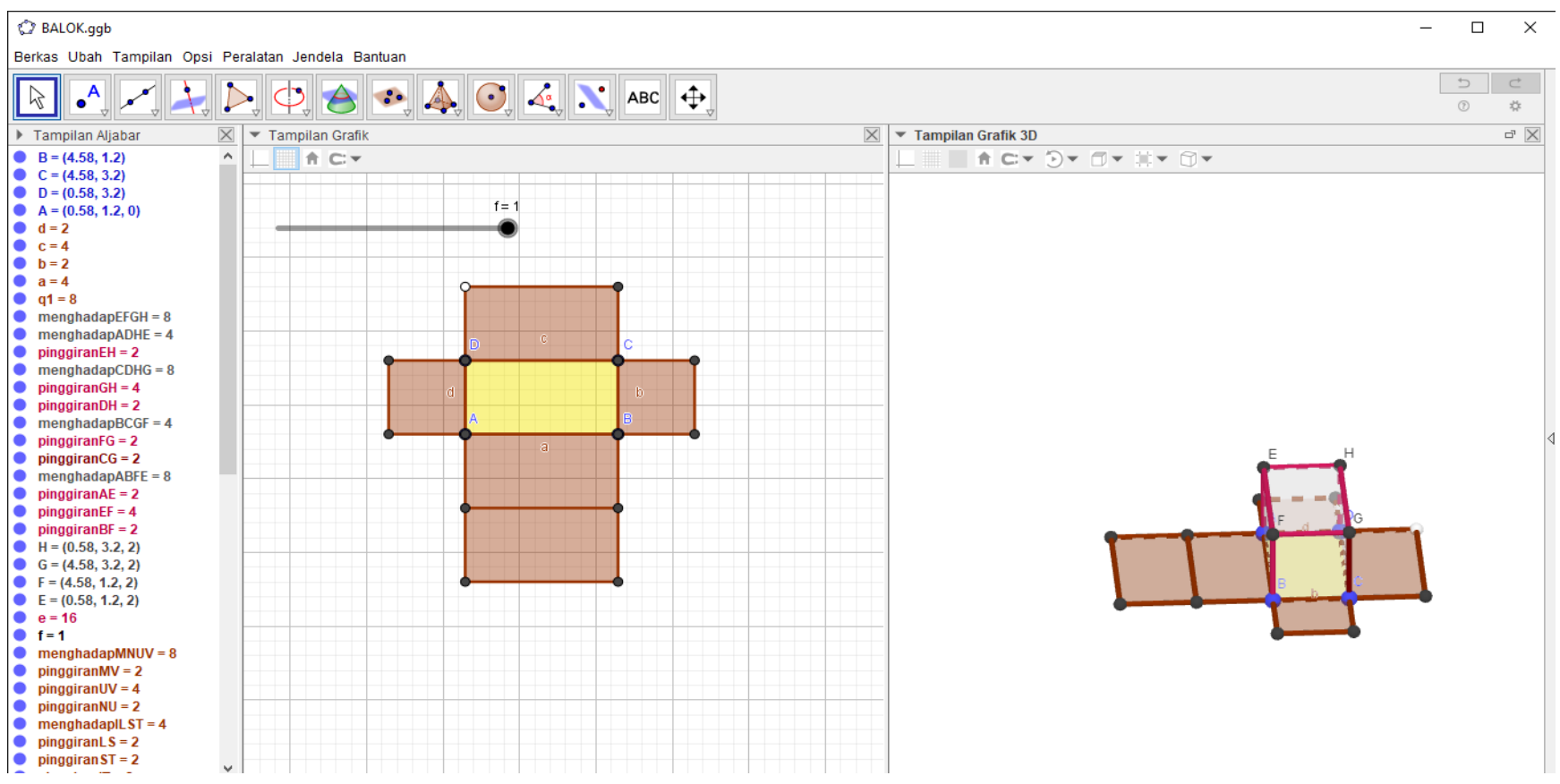

Gambar 1. 4 Balok

Pembuatan Balok dengan menggunakan aplikasi Geogebra dapat memudahkan guru menjelaskan materi bangun ruang balok. Dengan aplikasi geogebra, daya imajinasi siswa dapat dilatih dengan baik. Siswa pun dapat lebih mudah dalam menghitung luas, keliling dan volume balok. Karena dengan aplikasi geogebra, tampilannya berbentuk tiga dimensi, sehingga memudahkan siswa dalam memahaminya.

Program GeoGebra dapat dimanfaatkan sebagai media pembelajaran matematika. Dengan beragam fasilitas di dalamnya, GeoGebra dapat dimanfaatkan sebagai media pembelajaran matematika untuk mendemonstrasikan atau memvisualisasikan konsepkonsep matematis serta sebagai alat bantu untuk mengkonstruksi konsep-konsep matematis. $^{11}$

\footnotetext{
${ }^{11}$ M.Nur.
} 


\section{Pembelajaran E-Leaarning Berbasis Aplikasi Microsoft Teams}

Pembelajaran E-Learning merupakan proses pembelajaran dengan teknologi elektronik termasuk teknologi informasi dan komunikasi. Pembelajaran E-Learning bisa meliputi konten teks, presentasi, audio, dan video. ${ }^{12}$

Pandemi Covid-19 membuat pembelajaran di Indonesia berubah secara total. Adanya kebijakan dari pemerintah pusat untuk selalu menjaga jarak dan menghindari kontak langsung, baik antara guru dan siswa, maupun antara siswa dengan siswa yang lainnya membuat guru harus bisa menjadi lebih kreatif dalam menggunakan aplikasi software kelas virtual agar pendidikan tidak mengalami kelumpuhan total. Kelas virtual adalah kelas E-Learning yang memfasilitasi antar pengguna untuk berkomunikasi, melihat presentasi atau video, berinteraksi dengan peserta lain baik secara individu maupun berkelompok. Salah satu apikasi yang digunakan adalah adalah Microsoft TEAMS.

Beberapa tahun terakhir, dalam dunia pendidikan terdapat banyak sekali perubahan yang menuntut guru untuk mengadopsi teknologi ke dalam pendidikan, tidak terkecuali dalam pembelajaran Matematika. Microsoft teams adalah produk layanan berlangganan yang ditawarkan oleh Microsoft sebagai bagian dari lini produk Microsoft Office. Secara umum, fasilitas Microsoft 365 terdiri dari perangkat lunak Microsoft Office serta perangkat lunak berbasis komputasi awan sebagai produk layanan untuk lingkungan bisnis, seperti Hosting Exchange Server, Skype for Business Server, dan SharePoint ditambah opsi tambahan layanan Windows 10 Enterprise. Semua paket Microsoft 365 diperbarui otomatis tanpa biaya tambahan. ${ }^{13}$

Berikut beberapa pengertian E- learning dari berbagai sumber: ${ }^{14}$

1. Pembelajaran yang disusun dengan tujuan menggunakan sistem elektronik atau komputer sehingga mampu mendukung proses pembelajaran

\footnotetext{
${ }^{12}$ Tri Hanung Widiyarso and Sutama, "Efektifitas Penggunaan Microsoft Teams Dalam Pembelajaran ELearning Bagi Guru Selama Pandemi Covid-19," Jurnal Pendidikan Dan IImu Pengetahuan 21, no. 1 (2021): $15-21$.

${ }^{13}$ Widiyarso and Sutama.

${ }^{14}$ Widiyarso and Sutama.
} 
2. Proses pembelajaran jarak jauh dengan menggabungkan prinsip- prinsip dalam proses pembelajaran dengan teknologi.

3. Sistem pembelajaran yang digunakan sebagai sarana untuk proses belajar mengajar yang dilaksanakan tanpa harus bertatap muka secara langsung antara guru dengan siswa.

Dari beberapa pengertian e-learning diatas, penulis dapat mengambil suatu kesimpulan bahwa e-learning adalah suatu sistem pembelajaran yang menggunakan media atau teknolog sebagai sarana pendukung berlangsungnya pembelajaran.

\section{Fitur Microsoft Teams}

Microsoft Teams adalah hub digital aplikasi cloud yang menyatukan percakapan, rapat, file, dan aplikasi dalam satu Sistem Manajemen Pembelajaran (LMS) tunggal. ${ }^{15}$

Microsoft teams memiliki banyak fitur didalamnya, salah satunya adalah percakapan lewat teks tertulis, obrolan video, obrolan video kelompok, dll. Di dalam obrolan video grup pun terdapat berbagai fitur menarik lainnya, salah satunya adalah bisa berbagi layar, sehingga guru dapat dengan mudah menyampaikan materi kepada siswa lewat ponsel cerdasnya, lewat tablet, maupun lewat pc/laptop yang dimilikinya.

${ }^{15}$ Widiyarso and Sutama. 
Berikut adalah beberapa tampilan fitur utama yang dimiliki Microsoft teams

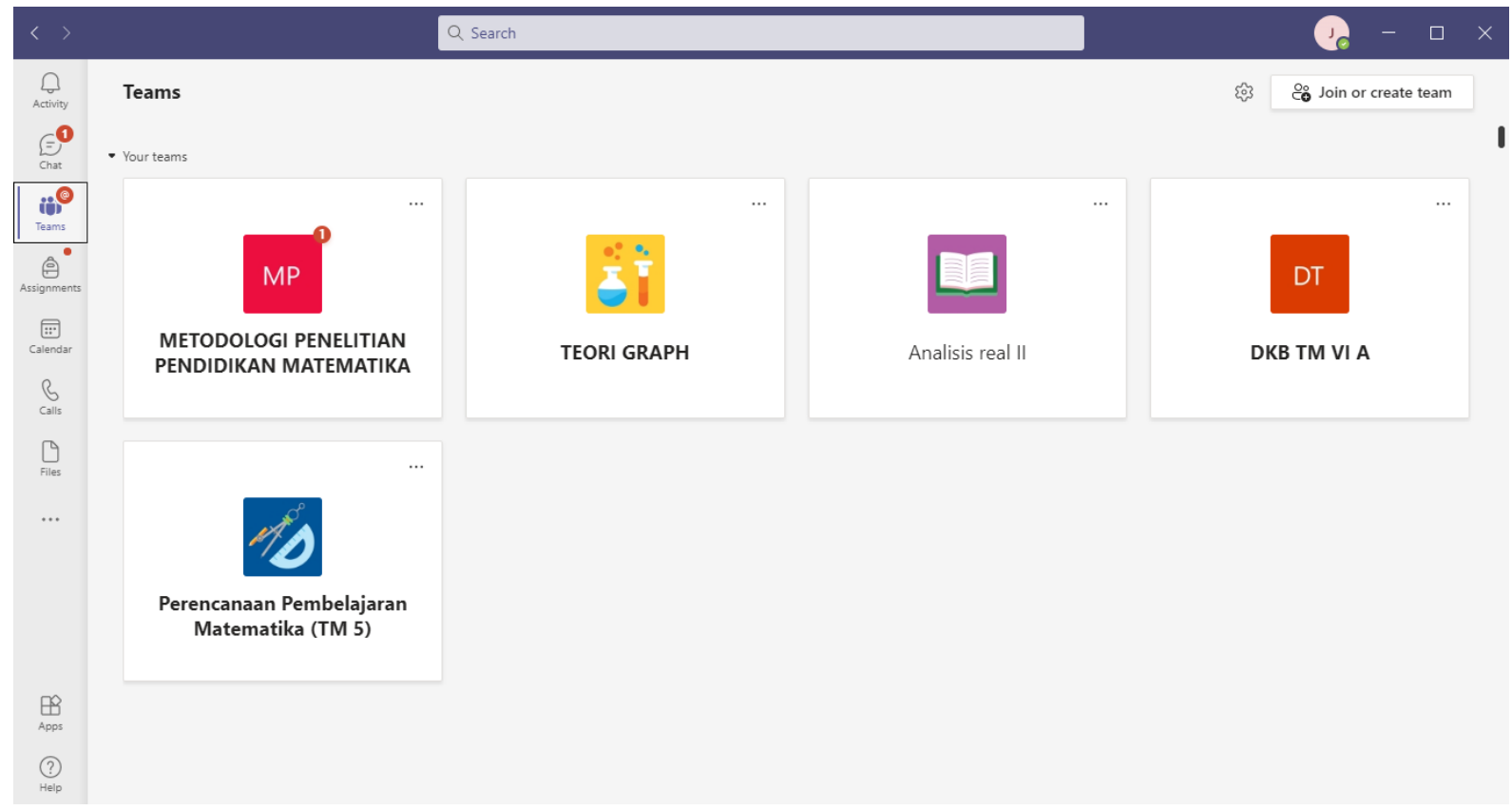

Gambar 1.5 Layout Microsoft Teams

\section{Keunggulan Microsoft Teams ${ }^{16}$}

1. Sangat Mudah Mengelola Kelompok

Mengelola kelompok dengan mudah di microsoft teams, seharusnya ada pada setiap aplikasi grup kerja dengan itu maka setiap pengguna bisa dengan leluasa mengelola serta memanage kegiatan yang dilakukan.

2. Menyediakan mengedit dan berbagai file kemana saja

Fitur yang tak dapat dimiliki aplikasi video call adalah adanya layanan pengeditan file, dengan begitu maka semakin mudah kita dalam membuat file dimana saja dan kapan saja tanpa harus repot membuka aplikasi yang lainya itu keunggulan dalam bidang pengeditan file.

3. Menyediakan Kualitas video HD dan audio yang baik

Orang tak jarang mengeluh akan kualitas video yang buram atau terkendala sinyal diberbagai video conference yang lain. Kelebihan yang lain dari Microsoft Teams mempunyai keunggulan dalam kualitas video yang HD, tentunya sangat

\footnotetext{
${ }^{16}$ Widiyarso and Sutama.
} 
membuat orang menjadi nyaman saat melihatnya serta kualitas audio yang jernih serta jelas membuat lebih nyaman pada saat kita menggunakanya.

4. Berinteraksi secara pribadi maupun grub dengan saluran khusus

Berinteraksi di grub adalah hal yang menjadi prioritas membuat grub supaya terjalin hubungan sosial serta mempermudah kita dalam bertukar fikiran dan pendapat.

5. Hanya menyimpan percakapan penting

Setiap obrolan atau percakapan di grub disimpan di Microsoft Team hal ini memudahkan kita dalam hal mengetahui apa saja percakapan yang pernah kita buat dan kita sharing kepada setiap orang yang berada di grub tersebut.

6. Cepat menemukan apa yang dicari di obrolan percakapan

Percakapan atau obrolan setiap pertemuan pastinya jumlahanya tak sedikit dan tercampur antara yang penting dan tidak penting. Bisa jadi semua akan terhapus apabila kita tidak menyimpanya. Lain halnya dengan Microsoft Teams setiap kita mencari hal penting pasti sudah disediakan.

7. Keamanan langsung dari Microsoft

Bidang keamanan sangat diunggulkan mengapa karena di dukung langsung dan dikembangkan langsung oleh Microsoft yang kita kenal sebagai perusahaan software terbesar didunia dan pastinya dalam keamanan jangan ditanyakan lagi. Microsoft Teams juga menjaga data kita agar tetap aman.

8. Sangat mengutamakan privasi

Dalam hal privasi, ms teams membuat saluran tersendiri yang dapat dibuat di ms teams dengan begitu kerahasiaan data kita dan informasi terkait data pribadi bisa tersimpan rahasia maka selayaknya harus diunggulkan dan kelebihan setiap aplikasi harus mempunyai privasi yang biak dan rahasia tentunya.

Dengan menggunakan Microsoft teams, lebih memudahkan guru dalam melakukan pembelajaran daring. Karena guru dapat berbagi powerpointnya lewat obrolan video grup di dalam aplikasi. Sehingga dalam menjelaskan materi pembelajaran matematika jadi lebih mudah dan efisien. Selain itu guru juga dapat berbagi layar sehingga memudahkan 
guru untuk membagikan gambar ataupun dokumen yang mungkin tidak terdapat pada powerpoint.

Siswa juga memiliki kemudahan jika ada sesuatu yang belum atau kurang dipahami. Siswa dapa bertanya hanya dengan mengangkat tangan (salah satu fitur yang dimiliki ms teams) 


\section{A. Kesimpulan}

Matematika adalah salah mata pelajaran wajib di seluruh jenjang pendidikan, mulai dari SD, SMP, SMA, hingga pada perguruan tinggi. Matematika itu menyenangkan, namun pada kenyataannya, masih banyak yang beranggapan bahwa 'matematika itu sulit'. Dari paradigma inilah yang membuat banyak kalangan enggan atau bahkan malas untuk belajar matematika.

Di era globalisasi seperti sekarang ini, teknologi berkembang cukup pesat dan banyak membantu dalam berbagai kehidupan manusia, tak terkecuali dalam dunia pendidikan. Sebagai seorang guru, kita harus membantu menghilangkan pikiran-pikiran negatif peserta didik tentang matematika. Salah satunya adalah dengan memanfaatkan teknologi semaksimal mungkin.

Salah satu aplikasi yang dapat dimaksimalkan penggunaannya dalam dunia pendidikan adalah Edmodo, Whatsapp, Geogebra, Microsoft Teams, dan masih banyak lagi. Namun dalam makalah ini, penulis hanya membahas 4 aplikasi yang tertulis diatas.

Tiga dari empat aplikasi yang kita bahas merupakan aplikasi social untuk berinteraksi, sedangkan yang satunya lagi adalah aplikasi yang sangat berguna untuk menjabarkan persoalan matematika secara khusus.

Geogebra dapat kita gunakan untuk mendeskripsikan berbagai macam persoalan matematika dalam sebuah gambar berbentuk dua atau tiga dimensi. Geogebra memiliki banyak sekali kegunaan dalam pembelajaran matematika, salah satunya adalah untuk pembuatan kubus, balok, bola, lingkaran, segitiga, dll.

\section{B. Saran}

Dari pembahasan diatas, menunjukkan bahwa seorang guru haruslah lebih kreatif dan penuh inovasi agar dapat lebih meanfaatkan teknologi dalam pembelajaran guna menggiring semua orang untuk belajar matematika tanpa ada lagi pikiran-pikiran negative tentang matematika. 


\section{DAFTAR PUSTAKA}

Irawati, T. (2010). Pengelolaan Pembelajaran Matematika Berbasis Teknologi Informasi Untuk Meningkatkan Pemahaman Konsep Dimensi Tiga Di SMK Negeri 1 Sawit Boyolali. Tesis Magister Pendidikan, 24-34. Retrieved from http://eprints.ums.ac.id/9602/

Irmayanti, I., Islamiah, N., \& Syarifuddin, S. (2020). Analisis Sosiomatematika Berbasis Kearifan Lokal Dalam Pembelajaran Pada Siswa Sdn 224 Palae. JTMT: Jurnal Tadris Matematika, 1(2), 27-34. retrieved http://journal.iaimsinjai.ac.id/index.php/Jtm/article/view/482

Jupri, A. (2018). Peran Teknologi Dalam Pembelajaran Matematika Dengan Pendekatan Matematika Realistik. Seminar Nasional Matematika Dan Pendidikan Matematika, 303-314. retrieved from http://ejournal.radenintan.ac.id/index.php/pspm/article/view/2630.

M.Nur, Isman. (2016). Pemanfaatan Program Geogebra Dalam Pembelajaran Matematika. Jurnal Matematika Dan Pendidikan Matematika, 5(1) 10-19. Retrieved from http://staffnew.uny.ac.id/upload/132240454/penelitian/Makalah+17+Semnas+LPM+U NY+2011+_Pemanfaatan+GeoGebra+dalam+Pembelajaran+Matematika_.pdf

Mytra, P., Arsyad, M., \& Heriyanti, A. (2020). Kepraktisan Pembelajaran Menggunaknan Aplikasi Edmodo. JTMT: Jurnal Tadris Matematika, 1(2), 9-11. Retrieved from http://journal.iaimsinjai.ac.id/index.php/Jtm/article/view/467.

Nurhikmah, N., \& Ernawati, E. (2020). Pengaruh Model Team Assisted Individualization (Tai) Terhadap Kemampuan Berpikir Kritis Matematis Siswa Berbasis Media Whatsapp 1(2) 19-26. Retrieved from http://journal.iaimsinjai.ac.id/index.php/Jtm/article/view/469.

Nurjannah, N., Mirna, M., Nurlili, N., \& Imunandar, A. A. (2020). Analisis Kesalahan Siswa Dalam Memecahkan Masalah Pisa Ditinjau Dari Gender. JTMT: Jurnal Tadris Matematika 1(2), 1-8. $\quad$ Retrieved http://journal.iaimsinjai.ac.id/index.php/Jtm/article/view/466.

Rahayu, A., Ernawati, E., \& Rahim, R. A. (2020. Perbandingan Hasil Belajar Matematika Dengan Menggunakan Model Number Head Together (Nht) Dan Think Pair Share (Tps) Berbasis Media Whatsapp. JTMT: Jurnal Tadris Matematika, 1(2), 12-18. Retrieved from http://journal.iaimsinjai.ac.id/index.php/Jtm/article/view/468.

Rosalina, R. (2009). Pemanfaatan TIK Sebagai Media Pembelajaran Di Masa Depan. Jurnal Teknik Informatika, 16(1) 12-34 Retrieved from https://jurnalteknodik.kemdikbud.go.id/index.php/jurnalteknodik/article/view/11/11. 
Widiyarso, T.H., \& Sutama, S. (2021). Efektifitas Penggunaan Microsoft Teams Dalam Pembelajaran E-Learning Bagi Guru Selama Pandemi Covid-19. Jurnal Pendidikan Dan Ilmu Pengetahuan, 21(1), 15-21. Retrieved from http://journal.umsurabaya.ac.id/index.php/didaktis/article/view/5283. 